\title{
Revisiting the Polygenic Additive Liability Model through the Example of Diabetes Mellitus
}

\author{
Emmanuelle Génin ${ }^{a} \quad$ Françoise Clerget-Darpoux ${ }^{b}$ \\ aINSERM UMR1078, CHU Brest, Université Bretagne Occidentale, Brest, and bINSERM UMR1163, Institut Imagine, \\ Université Paris Descartes, Paris, France
}

\section{Key Words}

Polygenic additive model · Diabetes · Multifactorial disease ·

Heritability $\cdot$ Risk prediction

\begin{abstract}
Most studies on multifactorial diseases are performed under the assumption of a polygenic additive liability. In particular, missing heritability and individual risk scores are estimated under this model. In this paper, we use the example of diabetes to highlight the pitfalls of relying on such a model, when there are reasons to suspect etiological heterogeneity and/or departure from the hypotheses on the environmental factor effects.

(c) 2016 S. Karger AG, Basel
\end{abstract}

\section{Introduction}

The polygenic additive model is the cornerstone of many methods used in the study of diseases involving multiple factors, both genetic and environmental (the so-called 'multifactorial diseases') [1]. In this paper, we propose to revisit the theoretical foundations of this model and their implications through the example of diabetes mellitus, as it was one of the first diseases studied under this model. After a brief reminder of the hypotheses underlying the use of this model in the context of multifactorial diseases, we will discuss the first results obtained on diabetes mellitus, using this model in the light of present knowledge.

As initially proposed by Fisher [2] to explain quantitative traits, the polygenic additive model was not directly transposable to multifactorial diseases. Several authors have contributed to its extension by introducing the concept of liability and threshold to model non-Mendelian binary traits (for a review, see Fraser [1]); but it was Falconer [3] who made a decisive contribution in 1965, when he proposed to explain multifactorial diseases by an underlying liability depending on both genetic and environmental causes. In Falconer's model, the liability is assumed to be normally distributed, with the contribution of many weak and independent genetic and environmental factors. The disease status of an individual depends on whether their liability value is below or above a given threshold ('unaffected' and 'affected', respectively). Under this model, it becomes possible to estimate disease heritability from its prevalence in the general population and in relatives of affected individuals.

\section{KARGER 125}

(c) 2016 S. Karger AG, Base

0001-5652/16/0804-0171\$39.50/0

E-Mail karger@karger.com

www.karger.com/hhe
Françoise Clerget-Darpoux

INSERM UMR1163, Institut Imagine, Université Paris Descartes

24 Boulevard du Montparnasse

FR-75015 Paris (France)

E-Mail francoise.clerget@inserm.fr 
As pointed out by Falconer [3], using a polygenic additive liability for a multifactorial disease implies that:

Assumption 1: dominance and epistasis effects are negligible in the disease etiology;

Assumption 2: neither a genetic nor an environmental factor makes a major contribution.

One of the first diseases on which Falconer applied his liability model was diabetes [4]. He showed that the heritability of liability to diabetes strongly decreases with age (with estimates being 70-80\% for under 10-year-olds and $30-40 \%$ for over 50 -year-olds). Two explanations were proposed for this observation [5]:

1 Genetic heterogeneity: early-onset and late-onset diabetes are distinct entities;

2 Environmental exposure variability: the variability of exposure to environmental factors increases with age. In those days, the only information available to support or reject a disease model was the prevalence of this disease in the general population and among relatives of randomly sampled affected individuals from this population. The two explanations were thus tested using this information in two different datasets: in a Canadian dataset $[4,6]$ - for which only first-degree relatives of affected were available; the conclusions were that early-onset and late-onset diabetes were genetically different and that the group of people with 'intermediate' age at onset likely consisted of a mixture of the two genetic types [6]. Contrarily, using data sampled from the population in Edinburgh, UK - with different degrees of relatedness for the family members of affected individuals -, the conclusion was that early-onset and late-onset diabetes were the same genetic disease [5]. In the latter study, however, the authors were unable to explain the extent of the heritability estimated from different kinds of relatives and admitted that it raises doubts about the validity of the liability model for diabetes.

After more than four decades of studies in the field of diabetes, it is interesting to revisit the two explanations above.

\section{Genetic Heterogeneity in Diabetes}

In the early 1900s, the observed clinical heterogeneity of diabetes for, first, the age at onset and, later, after the discovery of insulin, for the dependence on insulin has already suggested some levels of genetic heterogeneity of diabetes (for a historical perspective, see Gale [7]). However, the prevailing view was that early- and late-onset diabetes were gradations of a same genetically deter- mined disease process. The discovery of an association between human leukocyte antigens (HLA) and diabetes - an association that was restricted to the more severe forms of diabetes characterized by an early onset and insulin dependence - marked a real shift in paradigm. It proved that there really existed two different types of diabetes, called 'type 1 diabetes' (the former, insulin-dependent and HLA-associated form) and 'type 2 diabetes' (the latter, insulin-independent and non-HLA-associated form), respectively [8-14]. The difference between the two forms was even reinforced by the discovery of the presence of auto-antibodies in insulin-dependent patients, which showed that type 1 diabetes was also an auto-immune disease $[15,16]$.

Many efforts have been devoted to understand the biology of the HLA component of insulin-dependent diabetes. Some DR-DQ trans-heterodimers $[17,18]$ were found to play a major role with an odds ratio of 38 for their carriers [17]. However, these heterodimers did not explain the whole HLA component of the genetic susceptibility of type 1 diabetes and did not allow for a clear classification of patients $[19,20]$. The HLA component of insulin-dependent diabetes is thus a good illustration of the huge gap existing between the detection of a genetic association and its biological interpretation as, after several decades of research, the mechanisms underlying HLA susceptibility still remain unclear. Moreover, it clearly challenges the second assumption underlying the polygenic additive liability model, namely the absence of any major contribution from a genetic factor.

The existence of a monogenic form of diabetes was also suspected in the 1970s (see Tattersall [21]). But it was only around 1990 that - thanks to highly polymorphic genetic markers (microsatellites) - the first mutated genes of a monogenic form of diabetes, namely Maturity-Onset Diabetes of the Young (MODY) [22], were located [23, 24]. This monogenic form - with an autosomal dominant mode of inheritance and a primary defect in pancreatic $\beta$-cell function - represents a small proportion of all diabetes, but adds to its etiological heterogeneity. Moreover, to make things more complex, MODY itself is not a single entity but presents a genetic, metabolic and clinical heterogeneity [25, 26], as more than 10 genes have been identified for MODY, with huge mutation heterogeneity.

Then came the era of genome-wide association studies (GWAS) using SNP chips and the discovery of a plethora of common SNPs associated with type 1 and type 2 diabetes. Up to now, more than 50 loci have been associated with type 1 diabetes, and twice as much with type 2 diabetes, with a very small subset of genes associated with 
both types (for recent reviews, see Prasad and Groop [27] or Yang and Chan [28]). Type 1 and type 2 diabetes are now clearly considered as different genetic entities.

However, the classification of diabetes into two main forms, type 1 and type 2, remains questionable [29-33]. In particular, for type 2 diabetes, the recurrence risk for siblings of obese index cases is similar to the risk for obese individuals in the general population; while for siblings of non-obese index cases, the risk is three times that of the non-obese general population $[29,30]$. Besides, the existence of patients who are clinically in the borderland between type 1 and type 2 diabetes - referred to as latent auto-immune diabetes in adults (LADA) [31] - questions the usual classification criteria (age at onset, the presence of auto-antibodies and required insulin therapy) [32-34].

\section{Environmental Exposure Variability in Diabetes}

Apart from questioning the genetic homogeneity of type 1 and type 2 diabetes, one should also reconsider the strong assumption made in the liability model of a random exposure to normally distributed environmental factors. As shown by Benchek and Morris [35], deviation from this assumption can lead to meaningless heritability estimates.

For type 1 diabetes, the steep rise in the incidence rate in the second part of the 20th century - and especially in the age group under 5 years old - suggests that a strong change in environmental exposure occurred during this period and that initiating factors are probably present in early childhood [36-39]. However, it is still unknown how widespread and random this initial exposure is [39]. Contrarily to type 1 diabetes, there are many observations on environmental factors involved in type 2 diabetes, which clearly violate the basic assumption of the polygenic additive liability model.

First, there clearly are some environmental factors with major effects. Not only has the impact of diet and physical activity on type 2 diabetes - and strongly related to this, a person's BMI - been known for a long time [40-43], but there is growing evidence of a relationship between gene expression and dietary fat [44] as well as a role of microbiota in diabetes [45]. The global prevalence of diabetes among adults (people over 18 years of age) has risen from $4.7 \%$ in 1980 to $8.5 \%$ in 2014 [46]. The rising prevalence of both obesity and diabetes is a consequence of increased sedentary lifestyles and a higher energy density of diets [47-49]. Weight loss by appropriate diets and physical

Revisiting the Polygenic Additive Liability

Model: Diabetes Mellitus activity are driving the guidelines of prevention, and adherence to these guidelines shows effectiveness by reducing the incidence rate of type 2 diabetes [50-52].

Second, the assumption of non-random exposure is undermined by results obtained through data collected from 1976 to 1991 on over 150,000 individuals from 75 communities in 32 countries, which clearly show that the increase in type 2 diabetes cases affects some parts of the world more than others. Lower-income groups in industrialized countries now face the greatest risk $[53,54]$.

Third, there is a strong suspicion that gene-environment interactions, while difficult to evidence, play an important role. An interaction has been shown between certain genotypes and lifestyle, with an attenuation of the adverse effect with higher physical activity levels or, conversely, an increase with low physical activity and Western diet [55-57]. In particular, the PPAR-gamma genotype is an important factor in response to dietary fat [58-60].

Last, the assumption of an independent transmission of genetic and environmental factors does not hold. Diet is clearly a non-genetic cause of risk resemblance between relatives and cannot be distinguished from genetic transmission in the polygenic liability model. Moreover, there is growing evidence that imprinting $[61,62]$ but also other epigenetic mechanisms, such as in utero gene promoter methylation $[63,64]$, play an important role in diabetes and diabetes-related phenotypes [65].

\section{Discussion}

The etiological heterogeneity of diabetes and the difficulty to correctly account for the change and high impact of environmental factors clearly challenge the use of a polygenic additive liability model. Actually, it is indeed reasonable to admit that - for diabetes as well as for any multifactorial disease - we still do not know how many genetic risk factors are involved and how these factors interact with each other as well as with the environment.

It is sometimes argued that considering a simplified model, even though incorrect, can be useful. This is true ... but only as long as (1) one does not rely on this model to perform estimations which are model dependent and (2) it does not prevent understanding the physiopathology.

The problem of using the polygenic additive model for estimating heritability of multifactorial diseases from familial data has an even greater deleterious impact when estimating missing heritability or individual risk scores through genomic data. This leads to an epidemic of the 
GIGO syndrome among geneticists [66]. Indeed, these meaningless estimations as well as their frequent misinterpretation are often brought forward to justify the search for other genetic factors through GWAS. Unfortunately, this is to the detriment of alternative strategies allowing the detection of gene $\times$ gene and gene $\times$ environment interactions, non-random effects of environmental factors and complex genetic effects underlying the already detected SNP associations. Yet, these alternative strategies are of primary importance if our aim is to achieve a better understanding of the genetic mechanisms underlying the observed phenomena rather than to explain phenotypic variance in populations.

Indeed, in our view, the main purpose of the genetic study of multifactorial diseases is to understand the etiology of the disease with the hope that this understanding will contribute to a better disease control and prevention. Such an objective is shunted around when assuming that all complex and heterogeneous pathological processes can be summarized by a single simplistic model.

This reductionist view has also led to the widespread belief that any SNP association can be explained by a single nucleotide change in a gene involved in the disease process ('a causal SNP'). The functional variation underlying the observed association at a SNP, however, is likely to be more complex, as has already been well illustrated for type 1 diabetes by its HLA component. HLA is not the exception, and complex biological mechanisms, which cannot be summarized by the effects of a single allele, are also expected to play a role in diabetes in the insulin gene, where a Variable Number Tandem Repeat (VNTR) located in the insulin gene promoter is probably the main player $[67,68]$, or in the CTLA4 gene, where gene-gene interactions have been described in a mouse model [69].

The problem of describing a genetic effect by a single SNP could also be questioned for IL2RA [70] and PTPN22 [71], given that this simple explanation was rejected for other auto-immune diseases. Two SNPs for IL2RA and three for PTPN22 are necessary to explain the data on multiple sclerosis [72] and on rheumatoid arthritis (RA) [73], respectively. Moreover, RA data provide evidence for an interaction between different PTPN22 polymorphisms [73]. As a consequence, RA risk estimates based only on the PTPN22 R620W missense variant [74] lead to misclassifying the PTPN22 genotypes in terms of risk for RA. This advance in the modeling of these susceptibility genes became possible by the information available on large samples of affected sib pairs.

Unfortunately, the focus on the detection of genetic factors and the prevailing use of GWAS for such a detec- tion have led to the naïve idea that family data are no longer useful. This idea is wrong. Linkage and association studies can, in fact, be complementary approaches as exemplified by the crucial information for modeling gene effects provided by the stratification of affected sib pairs on the different risk genotypes $[75,76]$.

Bypassing the modeling step and sticking with the single information of allelic SNP data in huge samples of patients and controls comfort the idea that a polygenic additive model adequately fits the observed data. In fact, association information alone is quite poor for facing the etiological heterogeneity and for understanding the genetic architecture of multifactorial diseases [77, 78]. Modeling the individual effect of genes involved in disease susceptibility may improve the power for testing gene $\times$ gene interaction. It will be, for example, interesting to reconsider the observation that the relative risk for type 1 diabetes conferred by PTPN22 is stronger in the lower-risk HLA categories than in the high-risk HLA category [79].

One cannot deny that gene identification through GWAS brought advances in the study of the different types of diabetes. However, even if for type 1 diabetes the involvement of the immune system and $\beta$ cells was comforted by the long list of identified genes [19], the biological interpretation of most genes associated with type 2 diabetes remains unclear [27]. More generally, the move from a candidate gene strategy to a more agnostic association search using genome-wide SNPs has clearly been successful at reporting novel associations, but less successful at bringing biological interpretation. We believe that the time has come to shift from the exclusive use of the polygenic additive model paradigm and to give room to more biologically driven models of diseases supported by the physiopathology and genetic knowledge specific to diseases.

We took the example of diabetes to question the assumption of an additive polygenic underlying liability to multifactorial disease. For Falconer [4], the use of the model for diabetes was more justified than for any other multifactorial disease: 'The concept of the underlying variability - the liability - is more clearly valid than for probably any other disease. Since the blood glucose level forms the basis of diagnosis this measurement must be closely correlated with liability'. However, Falconer himself was fully aware that heritability estimates provided by his model should not be used for making any inference on the genetic mechanisms underlying phenotypic expression and, after him, several authors have acknowledged the fact that there was a need to go beyond the 
polygenic additive model - in order to better understand the genetic architecture of complex traits. Rather than paraphrasing them, we will close this paper by some of their most illustrative quotes:

Falconer [3]: 'heritability is a way of expressing phenotypic correlation between relatives but in no way a measure of genetic causation of the disease'.

Gibson and co-workers [80]: 'I think the missing heritability problem is overblown, and the focus on hits that are significant genome-wide is distracting attention from more general concerns over the ability of genome-wide association (GWA) studies to fully describe the architecture of phenotypic variation. A lot of the confusion may arise because heritability seems often to be equated with genetic contributions'.

Lewontin [81]: 'the misunderstanding about the relationship between heritability and phenotypic plasticity [...] arises from the entire system of analysis of causes through linear models, embodied in the analysis of variance and covariance and in path analysis'.

Kempthorne [82]: 'The theory of correlation between relatives has been of vast importance in plant and animal breeding because it is possible to design and carry out experiments to estimate variance components in expressions for covariances between relatives. However, data on humans is observational and individuals are not randomly assigned to environments, so that estimation of heritability from such data is not on the same firm foundation as it is in plant and animal breeding contexts'.

Nelson et al. [83]: 'Geneticists have for many years been aware that this model is a simplification that does not accurately reflect the true nature of biological systems. However, because the research and commercial applications that adhered to this theory have remained productive despite this, no major efforts have been made to explore more biologically connected alternatives'.

\section{References}

$>1$ Fraser FC: The multifactorial/threshold concept - uses and misuses. Teratology 1976;14: 267-280.

-2 Fisher RA: The correlation between relatives on the supposition of Mendelian inheritance. Trans R Soc Edinb Earth Sci 1918;53:399433.

$\checkmark 3$ Falconer DS: The inheritance of liability to certain diseases estimated from the incidence among relatives. Ann Hum Genet 1965;29: 51-76.

4 Falconer DS: The inheritance of liability to diseases with variable age of onset, with particular reference to diabetes mellitus. Ann Hum Genet 1967;31:1-20.

5 Smith C, Falconer DS, Duncan LJ: A statistical and genetical study of diabetes. II. Heritability of liability. Ann Hum Genet 1972;35:281299.

-6 Simpson NE: Heritabilities of liability to diabetes when sex and age at onset are considered. Ann Hum Genet 1969;32:283-303.

7 Gale EA: The discovery of type 1 diabetes. Diabetes 2001;50:217-226.

$>8$ Singal DP, Blajchman MA: Histocompatibility (HL-A) antigens, lymphocytotoxic antibodies and tissue antibodies in patients with diabetes mellitus. Diabetes 1973;22:429-432.

$>9$ Cudworth AG, Woodrow JC: Letter: HL-A antigens and diabetes mellitus. Lancet 1974;2: 1153.

$>10$ Nerup J, Platz P, Andersen OO, Christy M, Lyngsoe J, Poulsen JE, Ryder LP, Nielsen LS, Thomsen M, Svejgaard A: HL-A antigens and diabetes mellitus. Lancet 1974;2:864-866.
11 Cudworth AG, Woodrow JC: Evidence for HL-A-linked genes in 'juvenile' diabetes mellitus. Br Med J 1975;3:133-135.

12 Svejgaard A, Platz P, Ryder LP, Nielsen LS, Thomsen M: HL-A and disease associations - a survey. Transplant Rev 1975;22:343.

13 Cudworth AG, Woodrow JC: Genetic susceptibility in diabetes mellitus: analysis of the HLA association. Br Med J 1976;2:846-848.

14 Thomson G, Bodmer W: The genetic analysis of HLA and disease associations; in Dausset J, Svejgaard A (eds): HLA and Disease. Copenhagen, Munsgaard, 1977, pp 84-89.

15 Bottazzo GF, Florin-Christensen A, Doniach D: Islet-cell antibodies in diabetes mellitus with autoimmune polyendocrine deficiencies. Lancet 1974;2:1279-1283.

16 MacCuish AC, Irvine WJ, Barnes EW, Duncan LJ: Antibodies to pancreatic islet cells in insulin-dependent diabetics with coexistent autoimmune disease. Lancet 1974;2:15291531.

17 Chuang LM, Wu HP, Tsai WY, Lin BJ, Tai TY: Transcomplementation of HLA DQA1DQB1 in DR3/DR4 and DR3/DR9 heterozygotes and IDDM in Taiwanese families. Diabetes Care 1995;18:1483-1486.

18 Clerget-Darpoux F, Babron MC, Deschamps I, Hors J: Complementation and maternal effect in insulin-dependent diabetes. Am J Hum Genet 1991;49:42-48.

19 Noble JA, Erlich HA: Genetics of type 1 diabetes. Cold Spring Harb Perspect Med 2012;2: a007732.
20 Pociot F, Akolkar B, Concannon P, Erlich HA, Julier C, Morahan G, Nierras CR, Todd JA, Rich SS, Nerup J: Genetics of type 1 diabetes: what's next? Diabetes 2010;59:1561-1571.

21 Tattersall RB: Mild familial diabetes with dominant inheritance. Q J Med 1974;43:339-357.

22 Fajans SS: Scope and heterogeneous nature of MODY. Diabetes Care 1990;13:49-64.

23 Bell GI, Xiang KS, Newman MV, Wu SH, Wright LG, Fajans SS, Spielman RS, Cox NJ: Gene for non-insulin-dependent diabetes mellitus (maturity-onset diabetes of the young subtype) is linked to DNA polymorphism on human chromosome 20q. Proc Natl Acad Sci USA 1991;88:1484-1488.

24 Froguel P, Vaxillaire M, Sun F, et al: Close linkage of glucokinase locus on chromosome $7 \mathrm{p}$ to early-onset non-insulin-dependent diabetes mellitus. Nature 1992;356:162-164.

25 Vaxillaire M, Froguel P: Monogenic diabetes in the young, pharmacogenetics and relevance to multifactorial forms of type 2 diabetes. Endocr Rev 2008;29:254-264.

26 Kim S: Maturity-onset diabetes of the young: what do clinicians need to know? Diabetes Metab J 2015;39:468-477.

27 Prasad RB, Groop L: Genetics of type 2 diabetes - pitfalls and possibilities. Genes 2015;6: 87-123.

28 Yang Y, Chan L: Monogenic diabetes: what it teaches us on the common forms of type 1 and type 2 diabetes. Endocr Rev 2016;37:190-222.

29 Hanson RL, Pettitt DJ, Bennett PH, Narayan KM, Fernandes R, de Courten M, Knowler WC: Familial relationships between obesity and NIDDM. Diabetes 1995;44:418-422. 
-30 Weijnen CF, Rich SS, Meigs JB, Krolewski AS, Warram JH: Risk of diabetes in siblings of index cases with type 2 diabetes: implications for genetic studies. Diabet Med 2002;19:4150.

- 31 Fourlanos S, Dotta F, Greenbaum CJ, Palmer JP, Rolandsson O, Colman PG, Harrison LC: Latent autoimmune diabetes in adults (LADA) should be less latent. Diabetologia 2005;48:2206-2212.

32 Gale EA: Latent autoimmune diabetes in adults: a guide for the perplexed. Diabetologia 2005;48:2195-2199.

33 Groop L, Tuomi T, Rowley M, Zimmet P, Mackay IR: Latent autoimmune diabetes in adults (LADA) - more than a name. Diabetologia 2006;49:1996-1998.

- 34 American Diabetes Association: Diagnosis and classification of diabetes mellitus. Diabetes Care 2010;33(suppl 1):S62-S69.

35 Benchek PH, Morris NJ: How meaningful are heritability estimates of liability? Hum Genet 2013;132:1351-1360.

- 36 Rewers M, LaPorte RE, King H, Tuomilehto $\mathrm{J}$ : Trends in the prevalence and incidence of diabetes: insulin-dependent diabetes mellitus in childhood. World Health Stat Q 1988;41: 179-189.

37 Onkamo P, Vaananen S, Karvonen M, Tuomilehto J: Worldwide increase in incidence of type I diabetes - the analysis of the data on published incidence trends. Diabetologia 1999;42:1395-1403.

- 38 Green A, Patterson CC; EURODIAB TIGER Study Group. Europe and Diabetes: Trends in the incidence of childhood-onset diabetes in Europe 1989-1998. Diabetologia 2001;44 (suppl 3):B3-B8.

-39 Gale EA: The rise of childhood type 1 diabetes in the 20th century. Diabetes 2002;51:33533361.

40 West KM, Kalbfleisch JM: Influence of nutritional factors on prevalence of diabetes. Diabetes 1971;20:99-108.

41 Manson JE, Rimm EB, Stampfer MJ, Colditz GA, Willett WC, Krolewski AS, Rosner B, Hennekens CH, Speizer FE: Physical activity and incidence of non-insulin-dependent diabetes mellitus in women. Lancet 1991;338: 774-778.

-42 Hu FB, Manson JE, Stampfer MJ, Colditz G, Liu S, Solomon CG, Willett WC: Diet, lifestyle, and the risk of type 2 diabetes mellitus in women. N Engl J Med 2001;345:790-797.

43 Hu FB, van Dam RM, Liu S: Diet and risk of type II diabetes: the role of types of fat and carbohydrate. Diabetologia 2001;44:805-817.

44 Jump DB, Clarke SD: Regulation of gene expression by dietary fat. Annu Rev Nutr 1999; 19:63-90.

-45 Tilg H, Moschen AR: Microbiota and diabetes: an evolving relationship. Gut 2014;63: 1513-1521.

46 World Health Organization: Global report on diabetes. WHO Library Cataloguing-in-Publication Data, 2016.
King H, Aubert RE, Herman WH: Global burden of diabetes, 1995-2025: prevalence, numerical estimates, and projections. Diabetes Care 1998;21:1414-1431.

48 Seidell JC: Obesity, insulin resistance and diabetes - a worldwide epidemic. Br J Nutr 2000; 83(suppl 1):S5-S8.

49 Wild S, Roglic G, Green A, Sicree R, King H: Global prevalence of diabetes: estimates for the year 2000 and projections for 2030. Diabetes Care 2004;27:1047-1053.

50 Lindstrom J, Ilanne-Parikka P, Peltonen M, et al: Sustained reduction in the incidence of type 2 diabetes by lifestyle intervention: follow-up of the Finnish diabetes prevention study. Lancet 2006;368:1673-1679.

-51 Yates T, Khunti K, Bull F, Gorely T, Davies MJ: The role of physical activity in the management of impaired glucose tolerance: a systematic review. Diabetologia 2007;50:11161126.

52 Dunkley AJ, Bodicoat DH, Greaves CJ, Russell C, Yates T, Davies MJ, Khunti K: Diabetes prevention in the real world: effectiveness of pragmatic lifestyle interventions for the prevention of type 2 diabetes and of the impact of adherence to guideline recommendations: a systematic review and meta-analysis. Diabetes Care 2014;37:922-933.

53 King H, Rewers M: Global estimates for prevalence of diabetes mellitus and impaired glucose tolerance in adults. WHO Ad Hoc Diabetes Reporting Group. Diabetes Care 1993 16:157-177.

54 Kell KP, Judd SE, Pearson KE, Shikany JM, Fernandez JR: Associations between socioeconomic status and dietary patterns in US black and white adults. Br J Nutr 2015;113: 1792-1799.

55 Grarup N, Andersen G: Gene-environment interactions in the pathogenesis of type 2 diabetes and metabolism. Curr Opin Clin Nutr Metab Care 2007;10:420-426.

-56 Santos MJ, Martinez HJ, Martinez-Gonzalez MA: Genotype-by-nutrition interaction: interpretation of epidemiological studies (in Spanish). Rev Med Chil 2007;135:792-799.

57 Cornelis MC, Hu FB: Gene-environment interactions in the development of type 2 diabetes: recent progress and continuing challenges. Annu Rev Nutr 2012;32:245-259.

58 Kadowaki T, Hara K, Kubota N, Tobe K, Terauchi $\mathrm{Y}$, Yamauchi T, Eto $\mathrm{K}$, Kadowaki $\mathrm{H}$, Noda M, Hagura R, Akanuma Y: The role of PPARgamma in high-fat diet-induced obesity and insulin resistance. J Diabetes Complications 2002;16:41-45.

59 Memisoglu A, Hu FB, Hankinson SE, Manson JE, De Vivo I, Willett WC, Hunter DJ: Interaction between a peroxisome proliferator-activated receptor gamma gene polymorphism and dietary fat intake in relation to body mass. Hum Mol Genet 2003;12:2923-2929.

60 Hunter DJ: Gene-environment interactions in human diseases. Nat Rev Genet 2005;6: 287-298.
61 Margaritte-Jeannin P, Clerget-Darpoux F, Hors J, Deschamps I: Testing parental imprinting in insulin-dependent diabetes mellitus by the marker-association-segregationchi 2 method. Am J Hum Genet 1995;56: 1080-1087.

-62 Moore GE, Abu-Amero SN, Bell G, Wakeling EL, Kingsnorth A, Stanier P, Jauniaux E, Bennett ST: Evidence that insulin is imprinted in the human yolk sac. Diabetes 2001;50:199203

63 Godfrey KM, Sheppard A, Gluckman PD, Lillycrop KA, Burdge GC, McLean C, Rodford J, Slater-Jefferies JL, Garratt E, Crozier SR, Emerald BS, Gale CR, Inskip HM, Cooper C, Hanson MA: Epigenetic gene promoter methylation at birth is associated with child's later adiposity. Diabetes 2011;60:1528-1534.

64 Pollin TI: Epigenetics and diabetes risk: not just for imprinting anymore? Diabetes 2011; 60:1859-1860.

65 Slomko H, Heo HJ, Einstein FH: Minireview: epigenetics of obesity and diabetes in humans. Endocrinology 2012;153:1025-1030.

66 Génin E, Clerget-Darpoux F: The missing heritability paradigm: a dramatic resurgence of the GIGO syndrome in genetics. Hum Hered 2015;79:1-4.

67 Bell GI, Horita S, Karam JH: A polymorphic locus near the human insulin gene is associated with insulin-dependent diabetes mellitus. Diabetes 1984;33:176-183.

68 Barratt BJ, Payne F, Lowe CE, et al: Remapping the insulin gene/IDDM2 locus in type 1 diabetes. Diabetes 2004;53:1884-1889.

-69 Hunter K, Rainbow D, Plagnol V, Todd JA, Peterson LB, Wicker LS: Interactions between Idd5.1/Ctla4 and other type 1 diabetes genes. J Immunol 2007;179:8341-8349.

70 Vella A, Cooper JD, Lowe CE, Walker N, Nutland S, Widmer B, Jones R, Ring SM, McArdle W, Pembrey ME, Strachan DP, Dunger DB, Twells RC, Clayton DG, Todd JA: Localization of a type 1 diabetes locus in the IL2RA/ $\mathrm{CD} 25$ region by use of tag single-nucleotide polymorphisms. Am J Hum Genet 2005;76: 773-779.

71 Giza S, Goulas A, Gbandi E, Effraimidou S, Papadopoulou-Alataki E, Eboriadou M, Galli-Tsinopoulou A: The role of PTPN22 C1858T gene polymorphism in diabetes mellitus type 1: first evaluation in Greek children and adolescents. Biomed Res Int 2013;2013: 721604.

72 Babron MC, Perdry H, Handel AE, Ramagopalan SV, Damotte V, Fontaine B, MullerMyhsok B, Ebers GC, Clerget-Darpoux F: Determination of the real effect of genes identified in GWAS: the example of IL2RA in multiple sclerosis. Eur J Hum Genet 2012;20: 321-325.

73 Bourgey M, Perdry H, Clerget-Darpoux F: Modeling the effect of PTPN22 in rheumatoid arthritis. BMC Proc 2007;1(suppl 1):S37. 
74 Begovich $\mathrm{AB}$, Carlton VE, Honigberg LA, et al: A missense single-nucleotide polymorphism in a gene encoding a protein tyrosine phosphatase (PTPN22) is associated with rheumatoid arthritis. Am J Hum Genet 2004; 75:330-337.

-75 Clerget-Darpoux F, Babron MC, Prum B, Lathrop GM, Deschamps I, Hors J: A new method to test genetic models in HLA associated diseases: the MASC method. Ann Hum Genet 1988;52:247-258.

76 Clerget-Darpoux F, Babron MC: Testing genetic models for IDDM by the MASC method. Genet Epidemiol 1989;6:59-64.
77 Bourgain C, Génin E, Cox N, Clerget-Darpoux F: Are genome-wide association studies all that we need to dissect the genetic component of complex human diseases? Eur J Hum Genet 2007;15:260-263.

78 Clerget-Darpoux F, Elston RC: Are linkage analysis and the collection of family data dead? Prospects for family studies in the age of genome-wide association. Hum Hered 2007;64:91-96.

79 Bjornvold M, Undlien DE, Joner G, Dahl-Jorgensen K, Njolstad PR, Akselsen HE, Gervin $\mathrm{K}$, Ronningen KS, Stene LC: Joint effects of HLA, INS, PTPN22 and CTLA4 genes on the risk of type 1 diabetes. Diabetologia 2008;51: 589-596.
80 Eichler EE, Flint J, Gibson G, Kong A, Leal SM, Moore JH, Nadeau JH: Missing heritability and strategies for finding the underlying causes of complex disease. Nat Rev Genet 2010;11:446-450.

81 Lewontin RC: Annotation: the analysis of variance and the analysis of causes. Am J Hum Genet 1974;26:400-411.

82 Kempthorne O: Heritability: uses and abuses. Genetica 1997;99:109-112.

83 Nelson RM, Pettersson ME, Carlborg O: A century after Fisher: time for a new paradigm in quantitative genetics. Trends Genet 2013; 29:669-676. 